\author{
Новосельиева Н.А., \\ отличник народного просвещения, \\ почётный гражданин города Пензы, \\ председатель кадровой комиссии \\ Пензенского областного комитета КПРФ, \\ Пенза, Россия
}

\begin{abstract}
Аннотация. Статья посвящена воспоминаниям автора о жизни и партийной деятельности своего отиа - Киселева Александра Ивановича. Киселев А.И. был ветераном Великой Отечественной войны, подполковником Красной Армии, кавалером орденов "Боевого Красного Знамени», «Отечественной войны» I и II степени. Являлся секретарём Пензенского городского комитета КПСС, депутатом Пензенского городского Совета народных депутатов и членом исполнительного комитета. В статье приводятся биографические данные, сведения об обучении, участии в индустриализации, в Великой Отечественной войне, в послевоенном восстановлении народного хозяйства, организации партийной работыл. В основу статьи положены воспоминания автора, персональные документы Киселева А.И., материаль прижизненных интервью.

Ключевые слова: история семьи, советский человек, жизнь в СССР, труд в СССР, история коммуниста, Пенза.
\end{abstract}

\title{
«WE ARE BEAR RESPONSIBILITY FOR THIS TIME TO THE END»
}

Novoseltseva N.A., Honorable Person in National Education, Honorary citizen of the city of Penza, Chairman of the cadre commission Of Communist Party of the Russian Federation (Penza Regional Committee) Penza, Russian Federation

\begin{abstract}
The article is devoted to memories of the author about the life and activities of the party her father - Kiselyov Alexander Ivanovich. Kiselev A. I. was a veteran of the great Patriotic war, the Red Army Lieutenant Colonel, was awarded the order of the Red Banner, order of the Patriotic War First and Second class. He was the secretary of the Penza city committee of the CPSU, a deputy of the Penza City Council of People's Deputies and a member of the executive committee. The article gives biographical data, information on training, participation of industrialization, in the great Patriotic war, post-war reconstruction of national economy, organization of party work. The article is based on the author's memories, personal documents of AI Kiselev, materials of intravital interviews.

Key words: The history of the family, the Soviet man, life in the USSR, work in the USSR, the history of the communist, Penza.
\end{abstract}


Такая нам судьба дана... Мы до кониа за это время отвечаем.

Живём без отдыха и сна -

Такая нам, товарищ мой,

Судьба дана.

Р. Рождественский

За последние десятилетия мы стали свидетелями изощрённых усилий власть предержащих, направленных на искажение или уничтожение памяти о советской истории, Великой Октябрьской социалистической революции и даже правды о войне с фашистами в 1941-1945 гг.

Сначала это было ельцинско-чубайсовское переименование главного советского праздника в фарисейский «День согласия и примирения», а затем оно ознаменовалось путинско-сурковской отменой праздничного 7 ноября вообще. В указах и постановлениях всё можно отменить. Однако свет Октября по прошествии столетия так ярок и благотворен, что росчерком пера с ним не справиться. Но к этому далеко не всё свелось. Была задействована огромная пропагандистская машина и ей, к сожалению, удалось добиться того, что многие наши соотечественники поддались ей и считают нашу революцию антипатриотической, сознание других россиян опутано. Горько, но сдвинулся разум даже у тех, кто жил при Советской власти и кому, казалось бы излишне разъяснять значение Великого Октября. Но делать это следует обязательно. Да, у нас не было сотни сортов колбасы и у каждого личного автомобиля, как в Швеции и США, но у нас было нечто гораздо большее. Было больше справедливости... А она для советских людей всегда была выше всего на свете, выше денег и других материальных благ. И революция, и Великая Отечественная война 1941-1945 гг. произошли во имя справедливости.

За что КПРФ борется сегодня? За справедливость. За то, во имя чего 100 лет назад был свершён Великий Октябрь и ради чего ярким светом сияла миру самая справедливая на земле Советская Социалистическая держава. Её свет не погас. И он обязательно обозначит человечеству верный путь в будущее.

В обращении ЦК КПРФ «Время встать под знамёна Великого Октября» говорится: «Наша страна лишается исторической перспективы. Олигархические кланы вполне устраивает тот факт, что наша страна стала бензоколонкой и лесопилкой для Запада. Им не нужен талантливый, грамотный и умелый гражданин нашего отечества».

Хочется пригласить читателей к размышлениям на эту тему. Эти мысли побудили меня к написанию статьи о моём отце, его жизненном пути в борьбе за справедливость, используя воспоминания, родословную семьи Киселёвых, интервью журналистов, оценки простыми людьми его человеческих качеств, а ещё трудовую книжку, которая во многом, как говорят, обогатила мою память. 
Мой рассказ - это честная память, и я могу твёрдо ручаться за это.

«Киселев Александр Иванович - настоящий коммунист-ленинец. Это типичный представитель поколения 30-40-х годов прошлого столетия, волевого, бескорыстного, мужественного, любящего народ и Родину, ради процветания которой готового пойти на любые жертвы. Таких, как Александр Иванович Киселев, любили люди за твёрдость убеждений, доброту и терпение. Таких бы, как он, да в Москву бы, в Центральный Комитет, тогда бы там и перевёртышей типа Горбачёва и Ельцина не было бы». Эти слова написаны в сборнике рассказов о войне «Помним и гордимся!» в 2015 году Геннадием Елизаровичем Горлановым, доктором филологических наук, профессором, заведующим кафедрой «Литература и методика преподавания литературы» Пензенского государственного университета, членом Союза писателей России.

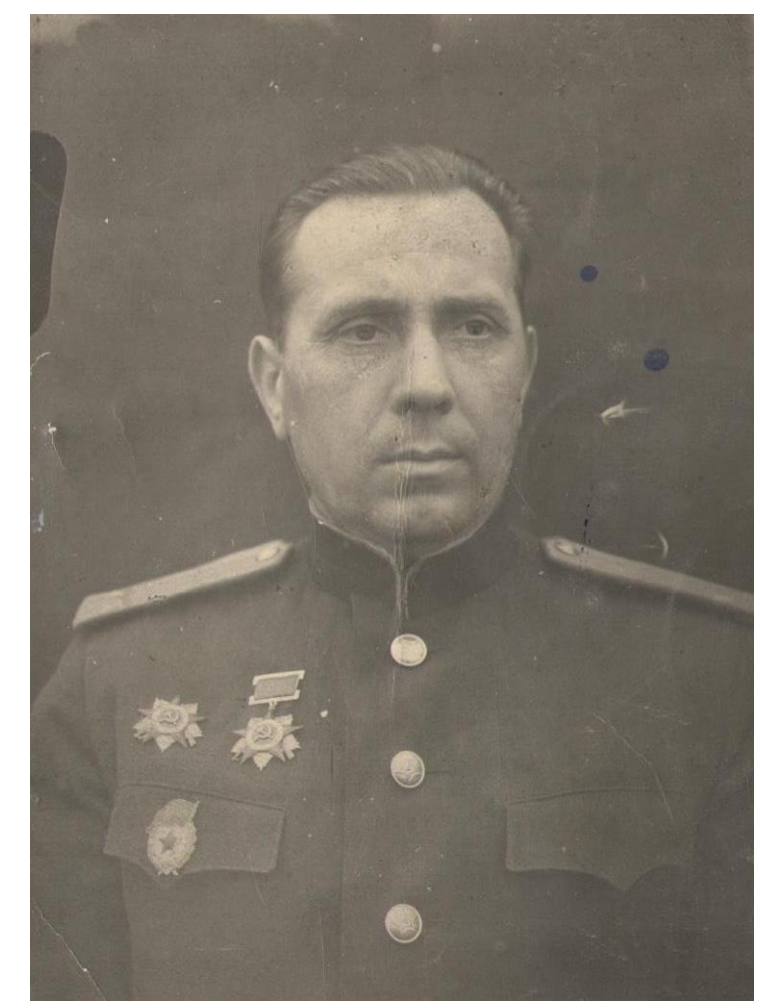

Рис 1. Киселев Александр Иванович

Киселев А.И. - коренной пензяк. Родился 23 ноября 1903 года в многодетной семье сапожника. Он рос вместе со своей страной, верил в социализм, воспитывался комсомолом, коммунистической партией. Своим народом. И им без остатка отдал всю свою жизнь. А ещё он был альтруистом, горячо любящим свою Родину, с постоянной готовностью прийти на помощь людям в трудную минуту.

Наша семья была дружной. Мама с папой прожили вместе полвека и для нас, детей - Нины, Нинель, Владимира родители во всём были примером. Я до сих пор помню слова отца: «будьте честными в большом и малом, любите людей». 
В будущем все его дети стали коммунистами и были верны партии до конца. Наш брат Володя умер в 2016 году в г. Северодонецке, где состоял в компартии Украины. Из семьи я осталась одна, что обязывает меня защищать сегодня настоящих советских людей, рождённых Октябрём. Умер папа в семьдесят два года от ишемической болезни сердца. Врачи сказали: «всё сердце в многочисленных шрамах - рубцах от инфарктов». И не мудрено, время для страны и каждой семьи было трудное. Но мы верили в светлое будущее, верили совершенно искренне. И мне, кажется, что хорошо жили в нём, хотя многого ещё добиться не удалось.

Как всё начиналось? В 1920 году Саша Киселёв вступил в комсомол и до 1922 года работал инструктором укома комсомола (уездного комитета). Бурная общественная, комсомольская работа, энтузиазм молодых, горячие споры, диспуты и, конечно, конкретные дела комсомольцев занимали всё свободное время.

В стране объявлен первый набор комсомольцев на флот. Александр по путёвке пензенского комсомола уезжает в легендарный Питер, в школу подводного плавания. Отлично учился и служил на флоте посланец комсомола: в Кронштадте, Ленинграде, Севастополе.

Окончив школу подводного плавания, класс электриков-подводников, он был зачислен в группу по подготовке старшин-электриков для подводных лодок Чёрного моря. А затем его направили в г. Севастополь, где он плавал до ноября 1925 года. Везде проявлял активность, большие организаторские способности, умение ладить с товарищами. Пятьдесят лет назад, давая интервью журналисту «Пензенской правды» А. Смайкину, папа рассказывал, как курсанты встретили смерть вождя революции В.И. Ленина: «Курсанты возвращались из тяжёлого похода. И, словно ножом в сердце, страшная весть: умер Ленин. Какими словами описать горе комсомольцев, чем измерить глубину их печали? Само собой пришло решение - в партию, ей - все силы, всю жизнь». Саша был верен этому решению до последних дней жизни.

В год ленинского призыва в партию, 1924, он был принят Ленинградской партийной организацией кандидатом в члены ВКП(б), а 19 октября 1925 года парторганизация Черноморского флота приняла его в члены ВКП(б).

Символично, что меня принимали в КПСС тоже в октябре месяце, но 1964 года. И отец давал мне рекомендацию в партию.

Курсы старшин-электриков, на которые были отобраны лучшие бойцы из школы подводников, вступили в ленинскую партию. И будто его, Сашину жизнь, подсмотрел и описал поэт:

Подшефный флот

подымай якоря,

В море

пора

подводным кротам.

«По морям,

по морям,

Нынче здесь, завтра там [2, с. 488]. 
Нынче здесь - учёба на Балтике, завтра там - Севастополь, служба на Чёрном море. С тех пор города Кронштадт, Ленинград, Севастополь стали для папы родными и он часто посещал их. Дорогими и родными они стали и для нашей семьи.

Подводные силы Черноморского флота по нынешним временам могут вызывать улыбку - шесть подводных лодок. Однако тогда на недостаток работы подводники пожаловаться не могли. И здесь виски старшины Киселева припорошила первая седина. Это после того, как экипажу пришлось прилагать поистине героические усилия, чтобы поднять с грунта повреждённую лодку. Отличной оценки заслужил на флоте посланец пензенского комсомола. Ему предлагали остаться на сверхсрочную службу, поступить на командирские курсы. Но властно звали его родные края. И он вернулся в город своей юности.

Нельзя сказать, что молодой коммунист с большим восторгом принял в Губкоме партии назначение заведующим секцией Губотдела труда в Пензе. Эта работа казалась ему канцелярской. Но опасения оказались напрасными - А.И. Киселев попал в самую гущу событий.

Страна взяла курс на индустриализацию. И людям, которым предстояло строить, творить, дерзать, давал путёвку в жизнь коммунист Киселев. Он разбирался с каждым человеком, которого рекомендовал куда-либо на работу. От его внимательности и добросовестности зависели судьбы людей. Свободное время выпадало редко. А тут ещё пришлось, засучив рукава, броситься в драку с троцкистами. Одним из них оказался его начальник. А для этого он перечитал немало книг, прежде чем научился наносить ощутимые удары капитулянтам и маловерам.

Подробно изучив жизненный путь отца, поняла, что он был прекрасным организатором и партийным вожаком.

ЦК партии заметил его организаторский талант и посылал его туда, где было трудно и надо было налаживать или поправлять дела. В предвоенные годы А.И. Киселев все силы, всю свою энергию отдавал делу строительства социализма.

Верхний Ломов встретил Александра Ивановича пожарами. Горели хлебные скирды, с них огонь перескакивал на дома сельчан. Немало крови попортили поджигатели секретарю волостного комитета партии, нелегко было их выловить. Но секретарь поднял на это активистов, и уничтожение народного добра было прекращено. Так началась работа молодого партийного вожака в деревне. Село переживало коренную перестройку. Крестьяне объединялись в колхозы, в деревне претворялись в жизнь заветы Ильича. И на этом решающем участке борьбы оказался рядовой ленинского призыва Александр Киселев. Бурные сельские сходы, долгие задушевные беседы с крестьянами, создание сельских партийных ячеек, выстрелы из-за угла месть озверевших кулаков... Сквозь всё это прошёл Александр Иванович, вырабатывая в себе качества руководителя, вожака, организатора масс. Здесь, в Верхнем Ломове у него родилась старшая дочь Нина. Папе пришлось работать и в Нижнеломовском райкоме ВКП(б) до ликвидации волости. После 
этого его избрали секретарём партколлектива фабрики «Победа». В феврале 1930 г. Окружком ВКП(б) удовлетворяет его просьбу и переводит на работу в г. Пензу.

Здесь раскрываются его педагогические организаторские способности. После окончания в 1918 году Высшего начального четырёхклассного училища папа работал агентом уездного отдела народного образования. Был обществоведом средней школы № 7, заведующим школой-семилеткой и зав. школой № 6 (образцовой) при Пензенском велосипедном заводе. Одновременно его избрали секретарём партячейки гороно. В 1933 году он возглавляет образцовую школу ОФЗД № 1.

Получается, что мы, его дочери пошли по его стопам. Нина Александровна была удостоена звания «Заслуженный учитель РСФСР», Нинель Александровна - «Отличник народного просвещения», продолжила его дело по партийной линии. 52 года служу народу и КПСС-КПРФ.

Прошло немного времени, и А.И. Киселев в 1935 году по заданию ЦК участвует в работе по созданию Оренбургской области. Он избирается первым секретарём четырёх сельских райкомов партии: Буртинского СреднеВолжского края, Тепловского, Ново-Орского, Мордово-Боклинского, где я и родилась. И лишь младший наш брат родился в Пензе.

В Оренбургской области отец участвовал в организации и укреплении колхозов, совхозов, МТС, вёл большую работу по воспитанию трудящихся, выработке у них высоких морально-нравственных качеств.

В мае 1938 года папа был отозван в ЦК ВКП(б) на учёбу в Высшую школу парторганизаторов. В декабре 1939 г. он получает новое, очень ответственное поручение: быть первым секретарём Оргбюро по Ашхабадской области. Тогда в Туркмении предстояло создать пять областей. Здесь А.И. Киселев работал до ноября 1941 года первым секретарём Ашхабадского обкома и горкома партии.

Началась Великая Отечественная война с фашизмом. Папа рвался на фронт, настойчиво писал заявления, звонил в ЦК, «бомбил все инстанции», хотя имел бронь. И добился своего: добровольцем ушёл на фронт.

Решением ЦК отца направили на курсы военных комиссаров при Академии имени В.И. Ленина. Там его избирают секретарём парторганизации. Затем он был командирован на курсы военкомов в г. Белебей и по их окончанию в мае 1942 г. был назначен вторым членом Военного Совета вновь формирующейся 27-ой Армии. После преобразования армии в Гвардейскую А.И. Киселева отзывают из-под Сталинграда и назначают начальником политотдела 23-ей Гвардейской стрелковой дивизии, где он воевал до октября 1943 года и был контужен. И в эти военные годы партия посылает нашего отца туда, где нужна помощь.

Наши оппоненты до сих пор пытаются нам внушить, что страна не была готова к войне и кадры военных были слабые, как и высшее военное руководство и т.П.

Биография моего отца и его рассказы говорят об обратном. Невольно позавидуешь тому, как в годы войны велась работа с кадрами. 
В ноябре 1943 года А.И. Киселева назначают на должность заместителя командира 7-ой Гвардейской Режицкой Краснознамённой стрелковой дивизии по политчасти и начальником политотдела этой дивизии. Она входила в состав 2-го Прибалтийского Фронта, Первой ударной Армии, которая освобождала Литву и Латвию.

Это всё статистика. А за ней: кровавые и жестокие бои, радость освобождения Прибалтики, мужество советских воинов, сотни тысяч погибших и 10 Сталинских ударов, которые решили исход войны. Папа не часто говорил о войне, больше о фронтовых друзьях. На войне были не только смерть и кровь, но и необыкновенная дружба, верность, самопожертвование. Мы подолгу рассматривали фронтовые фотографии, где перед боем солдатам и офицерам вручались партийные билеты и как комиссары личным примером вдохновляли воинов в бою.

В настоящее время об этих фактах умалчивают, комиссаров и политруков просто очерняют, оболган Верховный главнокомандующий И.В. Сталин, с именем которого шли в бой советские солдаты, оскверняются памятники советских полководцев, которые освобождали зарубежные страны.

Г.А. Зюганов на семинаре-совещании 28.01.17 г. говорил: «Мы обязаны показать, что только труд и справедливость сумели создать великое государство, одержать Победу, прорваться в космос, создать ракетноядерный паритет... И как только эти высокие идеалы, были преданы Горбачёвым, Яковлевым, Шеварднадзе, Ельциным, всё и посыпалось. И вот уже 25 лет страна кувыркается, встроившись в хвост американскому либерализму. Результат отрицательный. Хуже некуда. 80 тысяч производств и целые отрасли угробили» [1].

История - дама строгая. Она обязательно всё расставит по своим местам. В нынешней сложной международной обстановке мы не должны быть равнодушными и пассивными. Нам, коммунистам, нельзя останавливаться в борьбе за правду и справедливость. Активнее давать отпор всем фальсификаторам и антисоветчикам. Об этом хорошо говорилось на мартовском (2017 г.) пленуме ЦК КПРФ. Читая его материалы, вспомнила эпизоды из жизни нашей семьи.

Война закончилась. 1946 год. Мы живём по месту службы папы в г. Пярну Эстонской ССР. Я училась во втором классе и там была принята в пионеры. Сестра училась и закончила десятый класс.

Расскажу о двух случаях, которые очень долго я не могла понять, но они врезались в мою память навсегда. Едем с родителями на трофейной машине на рынок. Нас обстреливают «лесные братья», а местные продавцы молока вроде бы нас не понимают и не продают его нам. Сестра заканчивает десятый класс, но ей, как и другим детям военнослужащих, не выдают аттестаты зрелости, так как они не «смогли» сдать экзамены по немецкому языку. Так без аттестата зрелости и уехали в Пензу. Гораздо позже мы получили ответы на эти вопросы, но тогда это нам было не понятно. Отец всю послевоенную жизнь в Пензе вёл переписку с ребятами из нескольких районов Латвии, которые освобождала их дивизия. Им он отправил все военные 
фотографии, свои воспоминания, так как сам не мог по состоянию здоровья ездить на встречи. Недавно я обнаружила три письма из г. Виляны Лудзенского района и города Латвийской ССР от председателя Совета музея боевой Славы Вилянской средней школы Михаила Липина с отчётоминформацией о шестой традиционной встрече ветеранов воиновосвободителей 7-ой Гвардейской Режицкой Краснознамённой стрелковой дивизии и 37-й СД, поздравление Лудзенского райкома партии с 35-й годовщиной освобождения от немецко-фашистских захватчиков. Эта связь со школьниками Латвии грела душу отца, он всегда с удовольствием отвечал на их письма, а они ещё долго приходили и после его смерти.

В 1946 г. дивизию в г. Пярну расформировали. И снова, как в молодые годы на флоте, А.И. Киселев отказался от военной службы. Он был демобилизован в запас, и ЦК ВКП(б) направил его на работу в родную Пензу.

Подполковник Красной Армии Киселев А.И. за боевые заслуги награждён орденами Боевого Красного Знамени, Отечественной войны I и II степени, многими медалями. После войны он был награждён орденом «Знак почёта».

В Пензе его избирают секретарём Пензенского горкома партии (по идеологии), секретарём партколлегии обкома. Был он заведующим оргинструкторским отделом облисполкома, членом ревизионной комиссии обкома. Избирался депутатом Пензенского городского Совета народных депутатов и членом исполкома. И снова я вспоминаю, что тоже была секретарём по идеологии Пензенского горкома КПСС 9 лет (1983-1991 гг.)

Наступило время ухода отца на пенсию. Стал он пенсионером Союзного значения. Только не усидел дома, заскучал по работе, по людям. Коммунисты кирпичного завода избрали его своим партийным секретарём. И снова он в строю.

Работал он и в отделе кадров швейной фабрики имени К. Цеткин, где его очень любили наши женщины.

А.И. Киселев везде проявлял заботу о тех, кого незаслуженно обижали или наказывали. Думаю, что уход его на пенсию в 60 лет во многом связан с тем, что в высших эшелонах власти не для всех руководителей он был удобным человеком. Часто проявлял принципиальность, имел свою точку зрения и отстаивал её.

В последние годы жизни отец много сил и энергии отдаёт общественной работе в парткомиссии Ленинского райкома КПСС, являясь заместителем председателя комиссии. Частенько пошаливало сердце. Ходить домой на пятый этаж было трудно. И он нашёл выход: приглашал на разбор персональных дел товарищей домой. И сидя на кухне, в доброжелательной обстановке часами говорил с людьми. Конечно, не все дела решались положительно, но обиженных среди уходящих я не видела. У Александра Ивановича был талант слушать и слышать товарищей. Не всем это дано. От своей двоюродной сестры я узнала, что папа очень хотел, чтобы я продолжила его дело. Каким-то внутренним чутьём он увидел во мне «партийные задатки». И всю жизнь незаметно для меня готовил к тому, чтобы я заняла 
его место на партийном поприще. Так и получилось в будущем. Сама того не ведая и не стремясь к этому, я выполнила его мечту, хотя мне нравилось работать учителем.

Когда папа умер, к нам в дом приходило много людей. Я слышала их шёпот: «на таких должностях работал, а дома одни книги». А я вспомнила наш отъезд из г. Ашхабада. Огромный кованый сундук был набит книгами. Больше ничего не отправляли багажом. Папа был очень щепетильным человеком в бытовых вопросах и требовал от нас не допускать никаких излишеств. Читатель может сказать: «хвалитесь». Нет, хочу сказать: «Я горжусь тобой, папа и тобой, мама!»

Лидия Ильинична Киселева, фельдшер-акушерка по профессии, как и папа, из многодетной семьи, объездила с ним многие города и сельские районы. Где было возможно - работала. По своей натуре мама была человеком очень добрым. Работала заведующей районным отделом здравоохранения в сельской местности, нянечкой в детских яслях фабрики «Маяк революции». Не гнушалась никакой работой. Люди отвечали ей также добрым взаимоотношением. Она всю жизнь называла себя беспартийным коммунистом. Был в её жизни поступок, которым гордилась вся семья.

1953 год. Умер И.В. Сталин. Скорбела вся страна и наша мама. Она сумела убедить отца, настояла, чтобы её отправили в Москву проводить в последний путь любимого вождя. Улетела она в самолёте с гусями (в прямом смысле этого слова). В столице ничего не увидела, кроме сплошного потока людей и горя на их лицах. Вернулась домой. Но это был благородный порыв мамы, достоянный уважения нашей семьи.

Меня как-то спросили: «Какие черты вы цените в своём отце?» Ответила сразу, особо не задумываясь: «Высокий профессионализм, эрудицию, любовь к людям и, если можно так сказать, дотошность в работе, и то, что он вселял в нас неугасимый оптимизм». Таких людей, как папа я воспринимаю, как лики света Октября. А к ним я отношу своих учителей по жизни, дорогих моему сердцу товарищей по борьбе за справедливость. Это Зубков Борис Фёдорович, Харитонов Константин Петрович, Варлашин Николай Владимирович, Уришов Константин Петрович, Дорош Виталий Георгиевич, Лизунов Александр Яковлевич, Курбатская Лариса Андреевна. Они служили и служат нам примером, как и те, на кого мы с ними равнялись в довоенное и военное время: Зоя Космодемьянская и Олег Кошевой, Николай Островский и Павел Корчагин, Александр Матросов и 28 героевпанфиловцев, Ульяна Громова и Сергей Тюленин, Юрий Гагарин и Юрий Седов, Андрей Кижеватов и Василий Афанасьевич Глазунов, дважды Герой Советского Союза, наш земляк.

Конечно, есть люди и не столь знаменитые, но тоже несущие в себе черты советской эпохи, и их я тоже воспринимаю, как свет Октября. Сегодня трудно даже мысленно перенестись на сто лет назад, когда в недрах нашего общества вызрела великая революция. Однако биографии советских людей помогут это сделать. Мы с вами жили в судьбоносное время и, можно сказать, отвечали на его вопросы, каждый по-своему. Верно говорят, земля 
предков сама питает. Без истоков и корней человек не может устоять. Всех нас учили, что надо уметь постоять за правду, за справедливость, за Родину. Мы знаем, что такое трудовой энтузиазм, о котором всегда мечтали лучшие умы человечества, но он возможен только при социализме.

КПРФ - живой организм. В ней всегда есть противоречия. Вместе с тем, здоровая часть партии обязательно преодолеет все трудности. И мои товарищи по борьбе за справедливость, отстоявшие коммунистическую партию, будут укреплять её и сплачивать. Высокая дисциплина, ответственность, служение трудовому народу - этими принципами необходимо руководствоваться каждому и сегодня. Но надо обязательно сочетать великие идеи с заботой о ближнем. Любить всё человечество легко, а вот поддержать и помочь конкретным людям - это гораздо сложнее. Это я испытывала в жизни не раз. Что помогало - мои родители.

Мы идём к 100-летию Великой Октябрьской социалистической революции под флагом дружбы, труда и справедливости.

Нам всегда хочется видеть рядом с собой людей благородных, честных, способных на совершение поступков, двигающих общество вперед к социализму. Пусть рядом с Вами будет больше таких людей!

Начав стихами Р. Рождественского, мы заканчиваем свои воспоминания призывом В. Маяковского:

\author{
Светить всегда, \\ Светить везде \\ До дней последних донца, \\ Светить - \\ И никаких гвоздей! \\ Вот лозунг мой - \\ И солнца! [3, с. 164].
}

\title{
Источники и литература:
}

1. Зюганов Г.А. Выступление на семинаре-совещании 28.01.2017 [Электронный реcурc]. - https:// msk.kprf.ru

2. Маяковский В.В. Владимир Ильич Ленин // Маяковский В.В. Стихотворения и поэмы. - Л.: Лениздат, 1971.

3. Маяковский В.В. Необычайное приключение, бывшее с Владимиром Маяковским летом на даче // Маяковский В.В. Стихотворения и поэмы. - Л.: Лениздат, 1971.

4. Смайкин А. Сердце зовёт в бой // Пензенская правда. - 1965. - 22 апреля.

\section{Referenses}

1. Zjuganov G.A. Vystuplenie na seminare-soveshhanii 28.01.2017 [Jelektronnyj resurs]. https:// msk.kprf.ru

2. Majakovskij V.V. Vladimir Il'ich Lenin // Majakovskij V.V. Stihotvorenija i pojemy. - L.: Lenizdat, 1971.

3. Majakovskij V.V. Neobychajnoe prikljuchenie, byvshee s Vladimirom Majakovskim letom na dache // Majakovskij V.V. Stihotvorenija i pojemy. - L.: Lenizdat, 1971.

4. Smajkin A. Serdce zovjot v boj // Penzenskaja pravda. - 1965. - 22 aprelja. 